\title{
A Study on Knowledge Level of Farmers on Organic Red Gram Cultivation Practices in Dryland Areas of Karnataka, India
}

\author{
Akkamahadevi Naik ${ }^{*}$, M. Sreenivasulu, I. Sreenivasa Rao and Mahesh Lankati \\ Department of Agricultural Extension, College of Agriculture, Rajendranagar, Hyderabad \\ Professor Jayashankar, Telangana State Agricultural University, \\ Hyderabad-500 030, Telangana, India \\ *Corresponding author
}

\section{A B S T R A C T}

Keywords

Organic farming,

Knowledge level, Red

gram, Recommended

package of practice

Article Info

Accepted:

07 February 2018

Available Online:

10 March 2018
The study was conducted in Gulbarga district of North Karnataka. 66.60 per cent of the respondents were observed with medium level of knowledge on cultivation practices in dryland areas of Karnataka. However, majority $(50.00 \%)$ of the respondents belonged to young age and the respondents had low farming experience $(54.20 \%)$, followed by medium $(40.80 \%)$, majority of the respondents had medium perceived attributes $(54.10 \%)$, of which 54.20 per cent respondents had small farm size, but maximum number of them had medium socio-economic status $(54.20 \%)$, majority of the respondents had received medium level of training (46.60\%) and half of the respondents belonged to medium risk orientation $(55.00 \%)$.

\section{Introduction}

Organic farming is gaining momentum in India and particularly in Karnataka state, is at greater place because it is sustainable, adoptable and eco-friendly. Growing awareness of consumers to use safe and healthy food and need to address ill effects of chemicals in agriculture production, restoration of soil health and fertility has played a key role in the emergence of organic agriculture sector since last two decades. Red gram ranks sixth among pulses production in the world and is a major legume crop. The area under cultivation (4.5 million hectares) is stagnant. It is largely grown in the northern parts of the state especially in Gulbarga, which is called "Pulse bowl of Karnataka". In this district, Red gram occupied an area of $3,36,853$ ha and production of 1,53,285 tonnes. (Ministry of Agriculture, Govt. of India, 2014-15). Most farmers in Karnataka State are pioneers in organic agriculture and have developed many different systems of cultivation through indigenous knowledge base.

They have developed their own methods of using organic wastes and developed holistic pest control agents to control pests and 
diseases. Although, domestic market is at the early stage and unable to utilize the existing production potential, increased awareness towards healthy and safe organic foods have surged the demand for organic products especially in urban areas. It is witnessed that there is almost 20-25 per cent increased growth in organic sector per annum during the last 10 years. In spite of economic recession fears the growth of organic sector is unaffected. Organic farming practices are traditional in India, little comprehensive research has been done in India in general and Karnataka in particular from farmer's perspective. Hence this study was designed to unearth the level of knowledge on recommended organic production package of practices by organic red gram growers.

\section{Materials and Methods}

The research study was conducted in Gulbarga district of Karnataka state. This district was purposively selected as it ranks first in area and production of redgram. There are ten (10) mandals in Gulbarga district, among these, three mandals were selected randomly for the study. From each mandal two (02) villages i.e. a total of six (06) villages were selected randomly. From the prepared list, 20 farmers were selected by simple random sampling procedure from each village thus the total sample for the study constituted 120 farmers.

\section{Results and Discussion}

\section{Knowledge level of respondents on organic red gram practices}

Knowledge was operationalized as the "information and awareness possessed on recommended package of practices for organic red gram cultivation by the farmer". The respondents were grouped into following three categories based on exclusive class interval technique.
A perusal of the results in the table 1 majority $(66.60 \%)$ of respondents had medium level of knowledge followed by high $(24.20 \%)$ and low (19.20\%).

Hence, from the above results, it could be inferred that majority of the respondents had medium level of knowledge on organic Red gram practices. This result might be due to their, medium extension contact, medium level of socio-economic status; medium innovativeness, training received and risk orientation.

The respondents had sufficient traditional knowledge of cultivating organic red gram since decades, but lacks on modern knowledge of organic red gram cultivation, hence the trend follows in the study area. This finding is similar with Bhople and Borkar (2002) and Meena (2010).

The profile analysis of the respondents revealed that 39.20 per cent of them educated up to primary school level, majority $(50.00 \%)$ of the respondents belonged to young age group and 54.20 per cent of the respondents had small farm size but maximum number of them had medium socio-economic status $(54.20 \%)$, majority of the respondents had medium training received $(46.60 \%)$ and half of the respondents belonged to medium risk orientation $(55.00 \%)$. Hence, the results showed that majority of them had medium level of knowledge rather than high knowledge about cultivation practices.

Practice wise level of knowledge of respondents on organic red gram practices

The knowledge was measured with the help of schedule developed for the study consisting of 24 statements and respondents were asked for their response on these statements and for correct and incorrect responses the scores were 1 and 0 respectively. 
Table.1 Distribution of respondents based on their level of knowledge on organic red gram practices

\begin{tabular}{|c|l|c|c|c|}
\multirow{2}{*}{ SI. No } & \multicolumn{1}{|c|}{ Category } & Class Interval & \multicolumn{2}{c|}{ Respondents } \\
\cline { 3 - 5 } & & & Frequency & Percentage \\
\hline 1. & Low & $2-9$ & 17 & 19.20 \\
\hline 2. & Medium & $9-16$ & 80 & 66.60 \\
\hline 3. & High & $16-23$ & 23 & 24.20 \\
\hline
\end{tabular}

Table.2 Distribution of respondents based on their practice wise level of knowledge about organic red gram farming.

$(\mathrm{n}=120)$

\begin{tabular}{|c|c|c|c|c|c|}
\hline \multirow{3}{*}{$\begin{array}{l}\text { Sl. } \\
\text { No. }\end{array}$} & \multirow[t]{3}{*}{ Organic Red gram practices } & \multicolumn{4}{|c|}{ Respondents } \\
\hline & & \multicolumn{2}{|c|}{ Correct } & \multicolumn{2}{|c|}{ Incorrect } \\
\hline & & $\mathbf{F}$ & $\%$ & $\mathbf{F}$ & $\%$ \\
\hline 1. & The suitable soil type for Red gram & 105 & 87.50 & 15 & 12.50 \\
\hline 2. & The recommended Red gram varieties & 75 & 62.50 & 45 & 37.50 \\
\hline 3. & The type of seeds gives maximum yield & 75 & 62.50 & 45 & 37.50 \\
\hline 4. & The organic Red gram spacing between row to plant & 90 & 75.00 & 30 & 25.00 \\
\hline 5. & The suitable season for growing Red gram crop & 110 & 91.66 & 10 & 8.33 \\
\hline 6. & $\begin{array}{l}\text { The recommended dose of compost or farm yard manure in organic } \\
\text { Red gram cultivation }\end{array}$ & 95 & 79.16 & 25 & 20.83 \\
\hline 7. & After how many days of sowing, nipping can be done & 105 & 87.50 & 15 & 12.50 \\
\hline 8. & The important pest of Red gram crop & 110 & 91.66 & 10 & 8.33 \\
\hline 9. & The important disease of Red gram crop & 110 & 91.66 & 10 & 8.33 \\
\hline 10. & The use of spraying neem extracts to the crop & 85 & 70.83 & 35 & 29.16 \\
\hline 11. & The maximum number of pheromone traps are to be required per acre & 89 & 74.16 & 31 & 25.83 \\
\hline 12. & $\begin{array}{l}\text { The maximum liters of NSKE @ } 5 \% \text { formulation is required to spray } \\
\text { one acre to organic Red gram crop }\end{array}$ & 85 & 70.83 & 35 & 29.16 \\
\hline 13. & Before sowing seeds can be treated with...... & 100 & 83.33 & 20 & 16.66 \\
\hline 14. & The crops which are commonly grown as intercrop in Red gram. & 98 & 81.66 & 22 & 18.33 \\
\hline 15. & The organic nutrient management practices in Red gram farming & 100 & 83.33 & 20 & 16.66 \\
\hline 16. & At what stage of the crop growth the light trap can be used & 90 & 75.00 & 30 & 25.00 \\
\hline 17. & The optimum time for NPV is spray in a day & 99 & 82.50 & 21 & 17.50 \\
\hline 18. & The expected yield in organic Red gram cultivation & 90 & 75.00 & 30 & 25.00 \\
\hline 19. & $\begin{array}{l}\text { Deep summer ploughing destruction of crop residues helps for in-situ } \\
\text { moisture conservation and pest control. }\end{array}$ & 110 & 91.66 & 10 & 8.33 \\
\hline 20. & $\begin{array}{l}\text { Planting/sowing of pest resistant, early maturity varieties help to arrest } \\
\text { pest population. }\end{array}$ & 100 & 91.66 & 10 & 8.33 \\
\hline 21. & The nipping operation will increases the number of branches. & 115 & 95.83 & 5 & 4.16 \\
\hline 22. & $\begin{array}{l}\text { Store house should be maintained to the produce after harvest and } \\
\text { should be rat proof. }\end{array}$ & 100 & 83.33 & 20 & 16.66 \\
\hline 23. & FYM must be added before preparatory tillage. & 105 & 87.50 & 15 & 12.50 \\
\hline 24. & Before sowing seed treatment should be done. & 100 & 83.33 & 20 & 16.66 \\
\hline
\end{tabular}


Table.3 Relationship between independent variables and knowledge level of respondents in organic red gram practices

\begin{tabular}{|c|c|c|c|}
\hline Sl. No & Variable No. & Characteristics & Correlation coefficient (r) \\
\hline 1. & $\mathrm{X}_{1}$ & Age & $0.015 N S$ \\
\hline 2. & $\mathrm{X}_{2}$ & Education & $0.211 *$ \\
\hline 3. & $\mathrm{X}_{3}$ & Farm size & $0.241 * *$ \\
\hline 4. & $\mathrm{X}_{4}$ & Farming experience & $0.321 * *$ \\
\hline 5. & $\mathrm{X}_{5}$ & Socio-economic status & $0.221 *$ \\
\hline 6. & $\mathrm{X}_{6}$ & Annual income & $0.289 *$ \\
\hline 7. & $\mathrm{X}_{7}$ & Training received & $0.249 * *$ \\
\hline 8. & $\mathrm{X}_{8}$ & Risk orientation & $0.387 * *$ \\
\hline 9. & $\mathrm{X}_{9}$ & Innovativeness & $0.007 \mathrm{NS}$ \\
\hline 10. & $\mathrm{X}_{10}$ & Extension contact & $0.199 *$ \\
\hline 11. & $\mathrm{X}_{11}$ & Input availability & $0.267 * *$ \\
\hline 12. & $\mathrm{X}_{12}$ & Market intelligence & $0.048 \mathrm{NS}$ \\
\hline 13. & $\mathbf{X}_{13}$ & Perceived attributes & $0.279 *$ \\
\hline
\end{tabular}

* Significant at 0.05 level of probability

** Significant at 0.01 level of probability NS -Non Significant

Distribution of respondents according to the practice wise level of knowledge on the organic red gram farming in table 2 revealed that, majority of the respondents 95.83 per cent had knowledge regarding concept of the nipping operation will increases the number of branches, followed by 91.66 per cent of that red gram production in organic system following deep summer ploughing destruction of crop residues help for in-situ moisture conservation and pest control, the suitable season for growing red gram crop, the important pest and disease of red gram crop and planting/sowing of pest resistant, early maturity varieties help to arrest pest population, followed by 87.50 per cent of the respondents had knowledge on suitable soil type for red gram, after how many days of sowing; nipping can be done and FYM must be added before preparatory tillage, followed by 83.33 per cent of the respondents were following before sowing seed treatment should be done, store house should be maintained to the produce after harvest and it should be rat proof, the organic nutrient management practices in Red gram farming. Whereas majority of the respondents had knowledge in $(37.50 \%)$ the recommended red gram varieties, and type of seeds gives maximum yield, followed by $(29.16 \%)$ use of spraying neem extracts to the crop, and the maximum liters of NSKE @ 5\% formulation is required to spray one acre to organic Red gram crop, followed by 25.00 per cent of the respondents had knowledge on the organic Red gram spacing between row to plant, the maximum number of pheromone traps are to be required per acre, at what stage of the crop growth the light trap can be used and the expected yield in organic red gram cultivation, followed by 20.83 per cent of the respondents were had knowledge on the recommended dose of compost or farm yard manure in organic red gram cultivation, followed by 17.50 per cent of respondents were using the optimum time for NPV spray in a day and before sowing seed treatment should be done. It could be concluded that the respondents had sufficient knowledge regarding suitable season for organic red 
gram cultivation, timely sowing and planting to avoid pest and diseases, seed treatment methods, benefits of organic fertilizers, green manuring and FYM and about cultural practices followed in organic red gram cultivation, nipping operation and botanical pesticides. Whereas some respondents had limited knowledge about types of biofertilizers for organic Red gram cultivation, NSKE application, NPV spray quantity and time of application of farm yard manures, vermicompost, neem cake application, green manures, pheromone traps, bio-agents required for organic Red gram cultivation.

The results in table 3 revealed that, the formal schooling possessed by the farmer and the training received from any organisation on organic red gram cultivation definitely enhances the knowledge levels of respondents in organic red gram practices because the education acts as the bed rock and facilitates to synthesise comprehensively the external information into the given situation. Training received and extension contact by respondents sharpens the hidden skills and acts as a medium to imbibe any new knowledge or skill in a given profession. Hence, these variables were positively and significantly related to the knowledge level of respondents. This is on par with the findings of Obaiah (2004). The variables annual income and socio economic status had direct bearing on knowledge levels. The enhanced income levels of a farmer act as a driving force to search for new information for application in the field. Therefore, the annual income positively and significantly related with knowledge levels of organic respondents in organic red gram practices. This finding is in line with the results of Sudhakar (2002) and Obaiah (2004). The positive and significant relationship was observed between the variable organic inputs availability and knowledge levels of respondents in organic red gram practices. This can be justified based on the fact that respondents were purchasing inputs from nearby market or from any other private companies. This result is in agreement with the results generated by the Latha (2002) and Obaiah (2004).

The positive and significant relationship was observed between the variable farm size and knowledge. As size of the farm increases, correspondingly knowledge level increases. In the study area farmers with more farm size have multiple enterprises such as livestock farming, Integrated farming system, which makes them afford to take possible risk, if any in the initial period of organic farming where yields were low and unstable. Moreover from the bigger farm size, availability of manures, crop waste, compost, green manures were available in plenty which supports the farmers to adopt the organic practices.

Hence the farmer with larger farm size have medium to high risk taking ability and showed interest to know about organic red gram farming and attend training programmes, group meetings etc., which enables them to improve their knowledge towards organic red gram farming. Hence, the level of knowledge of respondents was positively and significantly correlated with the variable farm size. This is in line with the findings of Borkar et al., (2000) and Prasad et al., (2007). And there was a positive and significant relationship between farming experience and level of knowledge.

If a farmer is having more knowledge regarding the input preparation, time of sowing, precautions to control pest and disease, suitable variety to get maximum yield and market information, that may be due to his farming experience, so in this study there was a positive and significant relationship. This result is in agreement with the results generated by the Sarthak and Prabuddharay (2010) 
Knowledge level of the farmers about organic red gram farming practice was found to be medium. The profile characteristics of organic red gram practices like farming experience, training received, extension contacts, input availability and perception on attributes were significant with knowledge level of organic farmers. More number of agricultural information materials to be published by the department of agriculture on organic aspects, majority of the organic red gram respondents had young age; this indicates that the government should encourage the youth to take up farming as their profession, In order to update the knowledge level of the famers and also to increase the rate of adoption of organic farming practices, the public, private and NGOs should organize more need based location specific and specialized training programmes to the organic red gram farmers.

\section{References}

Bhople, R.S and Borkar, R.D. 2002. Biofertilizers farmer's attitude and adoption. Agricultural Extension Review. 14: 21-22.

Borkar, M.M., Chothe, G.D and Lanjewar, A.D. 2000. Characteristics of farmers influencing their knowledge about use of bio-fertilizers. Maharashtra Journal of Extension Education. 19: 130-131.

Latha, S.M. 2002. A study on knowledge and adoption of IPM practices in cotton by farmers in Kurnool district of Andhra Pradesh. M.Sc. (Ag.) Thesis. Acharya N $\mathrm{G}$ Ranga Agricultural University, Hyderabad, India.

Meena, M.S. 2010. Socio-economic study of organic farming in irrigated north western plain zone of Rajasthan. Agricultural Science Digest. 30: 94-97.

Obaiah, M.C. 2004. A study on capacity building of rice growing farmers of Farmers Field School (FFS) in Krishna Godavari zone of Andhra Pradesh. Ph. $D$ Thesis. Tamil Nadu Agricultural University, Coimbatore, India.

Prasadreddy, T.S., Prabhakar, K and Giddareddy, P. 2007. Analysis of influence of selected independent variables on knowledge of rice farmers on eco-friendly technologies. Journal of Research ANGRAU. 25(2): 31-37.

Sarthak, C and Prabuddharay. 2010. Knowledge level and adoption of the integrated pest management techniques: A study among the vegetable growers of Katwa sub-division, Bardhaman district. Indian Journal of Agricultural Research. 44: 168-176.

Sudhakar, B. 2002. Yield gap among integrated pest management oriented cotton growers under irrigated and rain fed conditions. A critical analysis. $P h$. $D$ Thesis. Tamil Nadu Agricultural University, Coimbatore. India.

\section{How to cite this article:}

Akkamahadevi Naik, M. Sreenivasulu, I. Sreenivasa Rao and Mahesh Lankati. 2018. A Study on Knowledge Level of Farmers on Organic Red Gram Cultivation Practices in Dryland Areas of Karnataka, India. Int.J.Curr.Microbiol.App.Sci. 7(03): 435-440. doi: https://doi.org/10.20546/ijcmas.2018.703.051 